УДК: 726:738.81(477-25)

\title{
Дарія Фінадоріна,
}

Національний Києво-Печерський історико-культурний заповідник, реставратор I категоріі

e-mail: dashfinador@ukr.net

\section{ЗАГАЛЬНА ХАРАКТЕРИСТИКА ЗНАХІДОК ПІЧНОЇ КАХЛІ КИЇВО-ПЕЧЕРСЬКОЇ ЛАВРИ}

Статтю присвячено розгляду колекиії пічної кахлі, яка походить з археологічних об'єктів, досліджених на території Києво-Печерського історико-культурного заповідника. У ї̈ складі присутні пічні вироби від $X V$ до XIX ст. включно, які ілюструють важливі сторінки з історії Києво-Печерського монастиря та, в деякій мірі, украӥнського кахлярства взагалі. Матеріал представлено за хронологічною періодизацією еволюції кахель. Найбільш ранніми знахідками у колекиії, що розглядається $\epsilon$ горщикоподібні кахлі $X V-X V I \mathrm{~cm}$. та кахлі з напівсферичним зовнішнім вигином у центрі пластини. Наступну за часом групу кахель у комплексі становить серія знахідок ранніх плиткових кахель XVI-XVII cm., 3 сюжетом декору, переважно сакрального та міфологічного змісту: 3 антропоморфними, тератологічними зображеннями та елементами давньоруської символіки. Найбільш численну групу в колекиії складають вироби XVII-XVIII cm. Кахля зазначеного періоду характеризується максимально повною репрезентативністю як в плані типологічних різновидів, так і в плані стилістичних варіантів оздоблення виробів. Завершальний етап розвитку украӥнського кахлярства ілюструють кахлі $X I X \mathrm{~cm}$.

У даній роботі ми представили найбільш яскраві та показові зразки пічної кахлі XV-XVIII cm. з території Києво-Печерського монастиря $з$ кожної хронологічної та типологічної групи, з деякими прикладами їх аналогів з синхронних пам'яток Печерську.

Цей масив матеріалу заслуговує більш всебічного наукового опраиювання і може включати у себе декілька окремих аспектів. Один з них полягає у спробі максимально чіткої хронологічної диференціачії зібраних кахель, “прив'язки” їх груп до певних етапів монастирської історії чи конкретних господарсько-побутових об 'єктів монастирської структури. До того ж, треба зауважити, що експонати колекиї наразі перебувають у різному стані збереженості. Більшість кахляних виробів потребує консервачійно-реставраційних заходів, за умови виконання яких колекиія може стати повночінною музейною збіркою пічної кахлі $X V-X I X \mathrm{~cm}$.

Ключові слова: археологічні знахідки Києво-Печерської лаври, пічна кахля, Новий та Новітній час.

$\Pi$

ічна кахля $є$ важливим елементом української культурної спадщини, який розкриває різні аспекти суспільного розвитку, від соціально-економічних до художньо-декоративних включно. Розповсюдження на українських територіях обігрі- 
${ }^{1}$ Виногродська, Л. І. (1997) До історії керамічного та скляного виробництва на Україні у XIV-XVIII ст. Археологія. (2), 129-142.

${ }^{2}$ Колупаєва, А. (2006)

Українські кахлі XIV-XX ст. Львів: б. в., 77-88.

${ }^{3}$ Івакін, Г. Ю., Балакін, С. А. (2001) Деякі підсумки археологічних досліджень на території Києво-Печерської лаври у 2000 р. Могилянські читання. (3), 126-135.

${ }^{4}$ Івакін, Г. Ю. (1996) Історичний розвиток Києва XIII середини XVI ст. К.: б. в., 87.; Оногда, О. В. (2008) Керамічні комплекси XIV-XVI століть 3 розкопок на території старого арсеналу. Лаврський альманах, (21), 24-31. вальних печей, а відповідно й пічної кахлі, наприкінці XIV - початку XV ст. пов'язується 3 посиленням західноєвропейських та польсько-литовських економічних та культурних впливів. 3 кінця XVI ст. кахлярство на українських теренах розвивається вже на власному грунті, поступово набуває національних рис і у XVIII ст. сягає свого найвищого розвитку. Протягом ХІХ ст. виготовлення кахлі переходить до мануфактурних та фабричних форм виробництва і значною мірою втрачає свою етнографічну специфіку1.

У даній роботі ми спробуємо проілюструвати генезу української кахлі матеріалами археологічних досліджень на території Національного Києво-Печерського історико-культурного заповідника. За останні тридцять років під час стаціонарних археологічних досліджень тут було зібрано досить численну та цікаву колекцію знахідок, що репрезентують практично весь період розвитку українського кахлярства від XV до XIX ст. включно.

Найбільш ранніми й тому рідкісними знахідками у згаданій колекції є горщикоподібні кахлі $\boldsymbol{X} \boldsymbol{V}-\boldsymbol{X} \boldsymbol{V I} \mathbf{c m} .3$ округлим отвором або румпою у вигляді квадрифолія.

Такі кахлі з’явилися на території Середньої Наддніпрянщини у кінці XIV - початку XVI ст. Вони мали форму горщиків та вмуровувались у стінки печі отворами назовні, а дном до вогню, для посилення тепловіддачі. За висотою, кутом нахилу стінок відносно дна 3-поміж них розподіляють архаїчні кахлі XIV - початку XV ст. та пізніші XV-XVI ст. Ознакою перших є висота тулуба 18-20 см та округлий отвір. Пізніші кахлі мають нижчий тулуб 13-14 см та більш розширений отвір круглої, квадратної, трикутної та квадрифольної форми. Поява квадратного чи квадрифольного отворів дала можливість викладання 3 кахель щільних рядів обличкування. У подальшому це зумовило появу суцільного кахляного покриття дзеркала печі. Взагалі фігурні отвори на горщикоподібних виробах започаткували декоративну функцію кахель у художній системі інтер'єру².

На території Києво-Печерського заповідника зразки горщикоподібної кахлі було виявлено в межах Соборної площі Верхньої лаври біля сучасного корпусу №4룬. Знахідки представлені двома різновидами форм. По-перше, це виріб циліндричної форми, 3 пласким круглим денцем та отвором у вигляді квадрифолія. Розміри виробів: висота - 20,0 см, діаметр денця - 8,0 см, розміри отвору - 10,0 х 10,0 см, поверхня неполив'яна (рис. 1.1, 1.2). По-друге - кахля з тулубом, у вигляді зрізаного конусу, з широким круглим вінцем та пласким денцем. Висота виробу - 12,0 см, діаметр отвору - 12,0 см, діаметр денця - 8,0 см, поверхня неполив'яна (рис. 2.1). Ще декілька уламків горщикоподібної кахлі було виявлено під час розвідкових досліджень 2015 р. у корпусі №4. Це фрагменти від кахлі з квадратним отвором, за висотою тулуба 13,0 см (приблизна висота, за аналогом з території Вознесенського монастиря), отвір - 5,0 х 5,0 см (рис. 2.2). Серед інших знахідок, 3 археологічних об’єктів Києва, рання горщикоподібна кахля походить з розкопок на Подолі, Верхнього Києва та Печерська4 .

3 наведеною вище групою ранніх кахель хронологічно межують т. зв. кахлі з пуклею-напівсферичним зовнішнім вигином у 
Мıсто: ІстоРІя, кУЛЬтУРА, суспільство

Рuc. 1.1, 1.2.

Горщикоподібні кахлі XV-XVI ст.
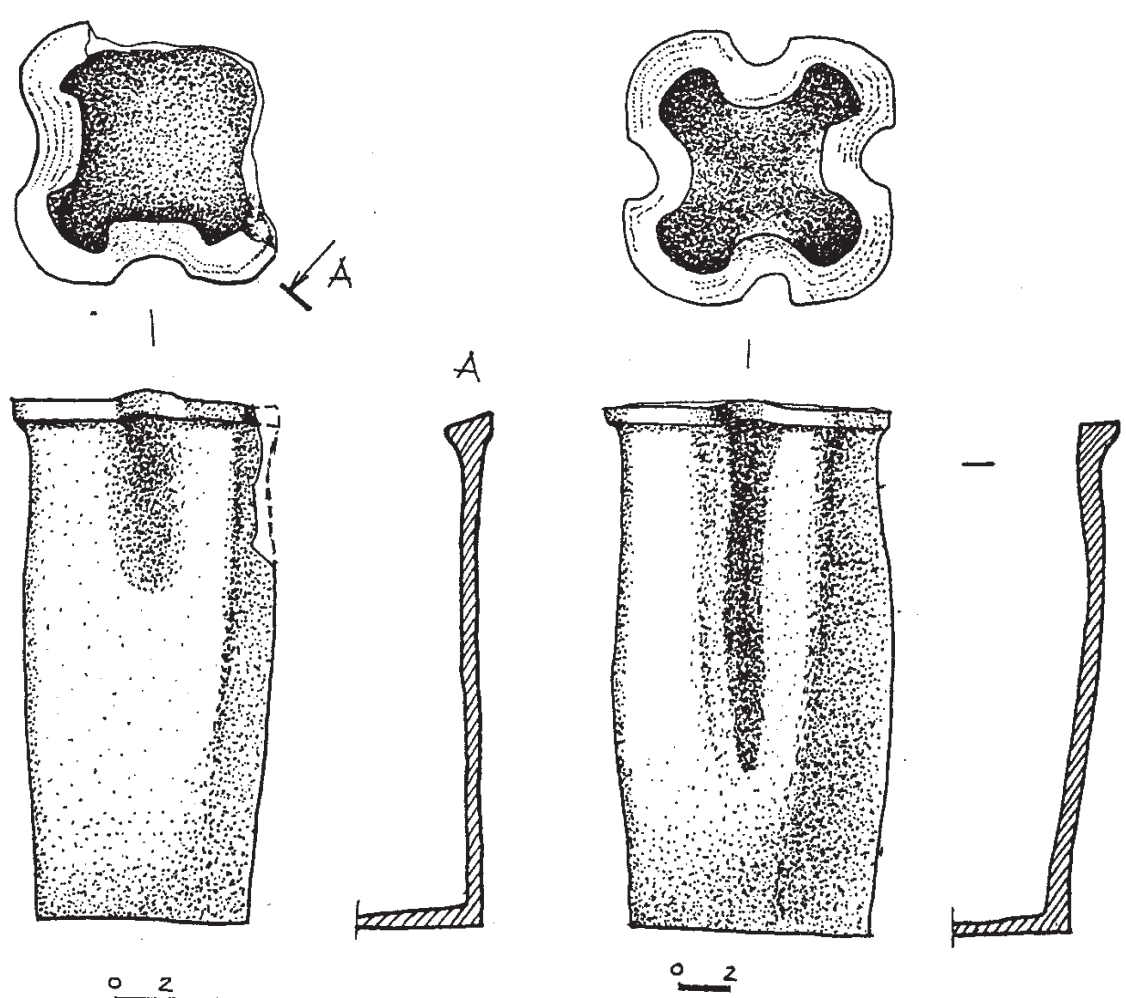

Рис. 2.1, 2.2. Горщикоподібні кахлі XV-XVI ст.
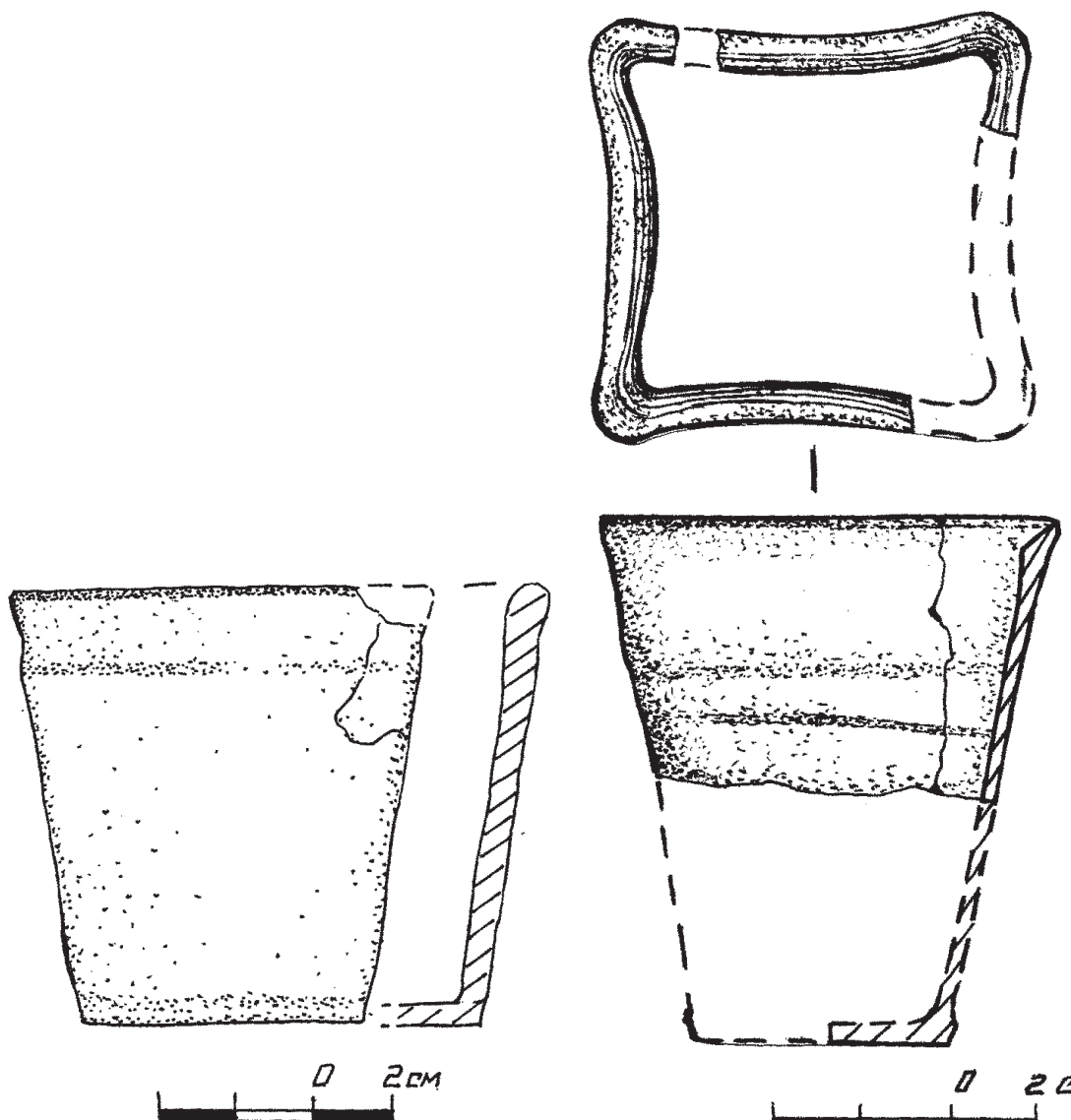

$1 \quad 2 \mathrm{CM}$ 
${ }_{5}^{5}$ Балакін, С.А. (2002) Звіт про результати археологічних досліджень на території Національного Києво-Печерського історико-культурного заповідника у 2001 р. К.: КПЛ - А - НДФ, (688).; Балакін, С.А., Зажигалов, О.В., Фінадоріна Д.В. (2015) Звіт про результати археологічних досліджень на території Національного Києво-Печерського історико-культурного заповідника у 2015 р. К.: КПЛ - А НДФ, (731).
Puc. 3.1, 3.2. Кахля XV-XVI ст. 3 “пуклею”. центрі пластини. Типологічно це зовсім інший (ніж горщикова кахля) тип керамічних виробів, з іншим методом кріплення до тіла печі, а, відповідно, й іншими морфологічними та технологічними параметрами. Фактично, це первинна форма звичайної для пізнішого часу виповнюючої коробчастої кахлі, від якої вона відрізняється меншими розмірами пластини (16,0 х 16,0 - 18,0 х 18,0 см), наявністю напівсферичного вигину по центру пластини та деякими іншими особливостями. На відміну від неполив'яної горщикової кахлі, кахля “з пуклею” часто-густо має полив'яну лицьову поверхню, зазвичай, зеленого кольору.

На території КПЛ знахідки таких виробів нечислені й значною мірою походять 3 розкопок на Соборній площі Верхньої лаври 5 . Зокрема, йдеться про майже повний зразок неполив' яної кахлі “"з пуклею”, розміри пластини якої 16,5 х 16,5 см, висота румпи - 9,0 см (рис. 3.1, 3.2). Тут же було виявлено фрагменти від двох лицевих виповнюючих кахель такого типу (з напівсферичним вигином по центру пластини), з елементами декору у вигляді стилізованого місяця та хрестоподібного орнаменту. Розміри пластини виробів - 21,0х21,0 см, висота румпи - 10,0 см; поверхня неполив'яна (рис. 4.1, 4.2). Полив'яні зразки кахлі “з пуклею” походять з розкопок Трапезної церкви Києво-Печерської лаври.

Наступну за часом групу кахель, становить серія знахідок ранніх плиткових (коробчастих) кахель XVI-XVII ст. Вироби цього часу зазвичай з квадратною пластиною з одноступінчатою рамкою, декорованою високим рельєфом. Сюжет декору - переважно
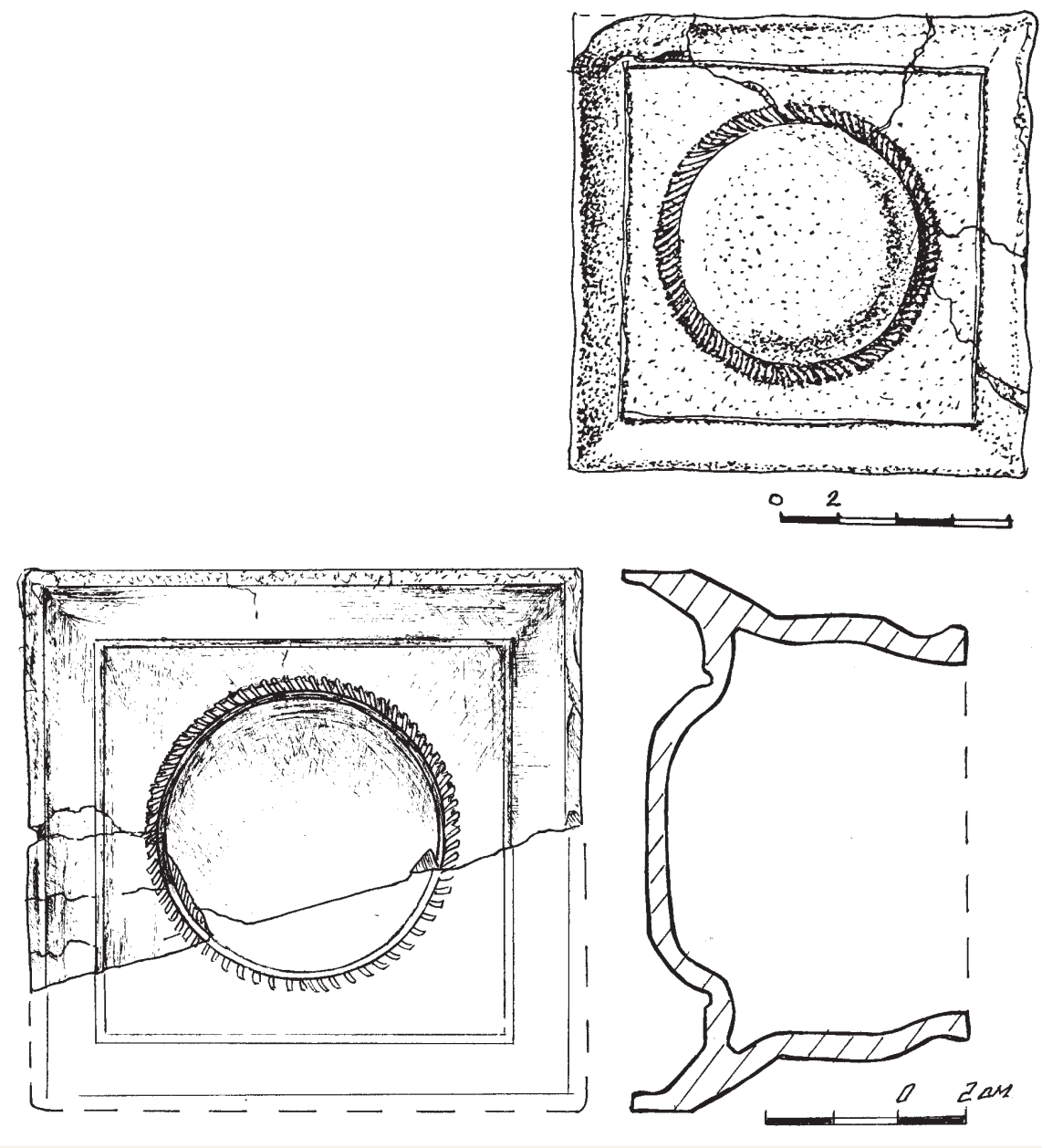


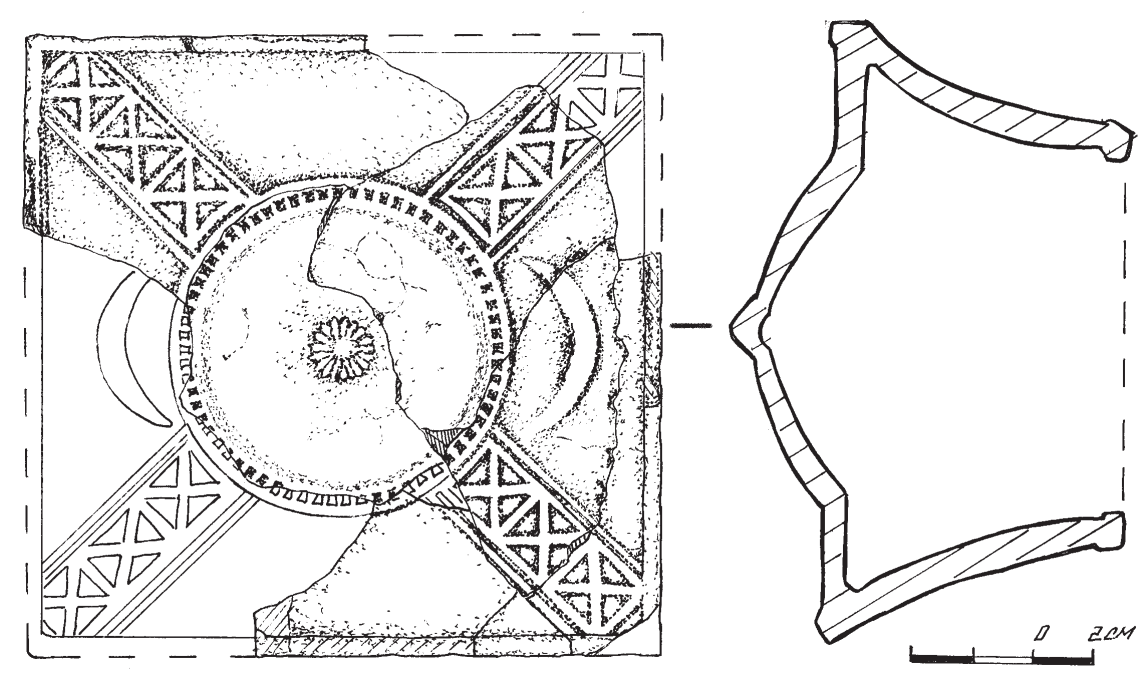

Puc. 4.1, 4.2.

Кахлі XVI ст. 3 “пуклею”.
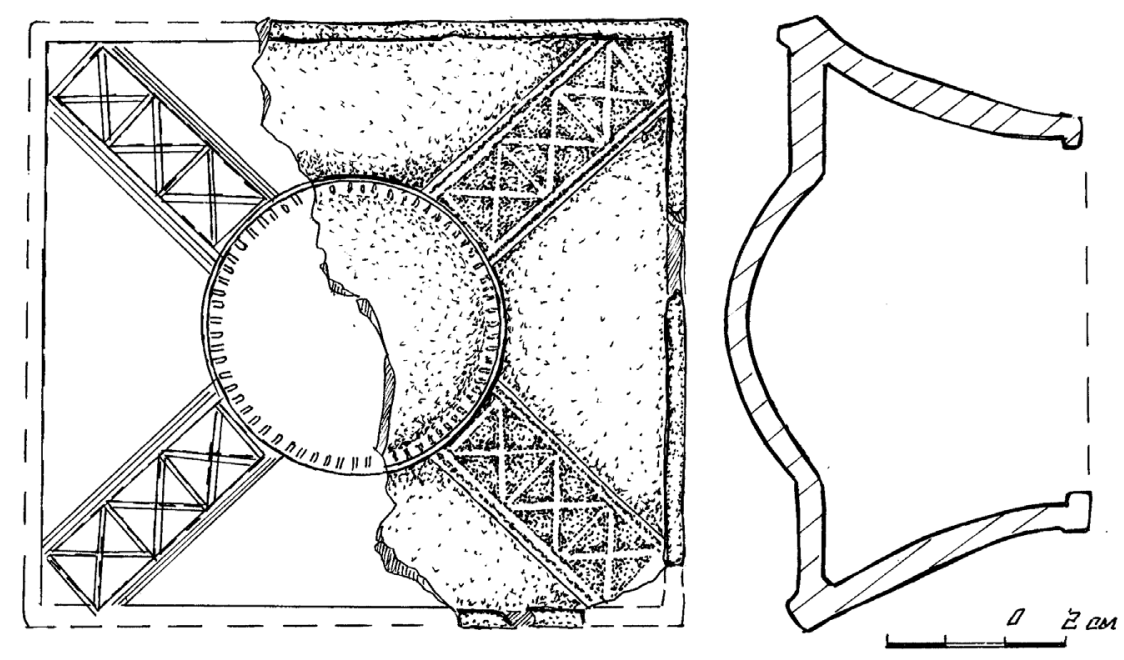

сакрального, міфологічного, змісту. Орнаментальна композиція складається з фігурних зображень (антропоморфних, тератологічних, геральдичних тощо) елементів давньоруської символіки (хрести, ромби, кола, зірки, солярні знаки).

Специфічною ознакою лаврського зібрання кахель XVIXVII ст. є повна відсутність тут, так званої, геральдичної кахлі і наявність поодиноких екземплярів кахлі з сакральними та сюжетними зображеннями.

Кахлі із декором сакрального змісту на українських теренах з'являються під впливом Західно-Свропейського мистецтва часів бароко, причому практично одночасно поширюється відразу декілька варіантів зазначеного сюжету. Так, на кахлях початку XVI ст. найчастіше трапляється зображення фігури ангела на повний зріст, зодягнутого у довге вбрання з музичним інструментом в руках. У православ 'ї це символізує небесний хор, вічну благозвучну хвалу Господу. Тоді ж з'являються кахлі з фронтальним погруддям ангела-охоронця. Вважається, що цей мотив увійшов до арсеналу українського мистецтва під впливом польського. Набуває поширення також і декорування карнизної кахлі з зображеннями херувимів з симетрично розправленими крилами - так звані голівки “путті". Крім того, на західноукраїнських землях у XVI- 
${ }^{6}$ Иконография ангелов и архангелов. Avaliable from: http://www.angelologia.ru/ iconographia/183 ikonografia angelov.htm. [Accessed May 14, 2016].

${ }^{7}$ Балакін, С.А. (2008) Трапезна церква та палата Печерського монастиря (археологічний аспект) Нові дослідження памяток козацької доби в Україні, (17), 41-48.
Puc. 5.1, 5.2. Кахлі XV-XVI ст.

3 сакральним зображенням.
XVII ст. відомі кахлі, декоровані популярними на той час іконописними сюжетами ${ }^{6}$.

У християнському мистецтві згадані образи були пов’язані як 3 традиціями певного художнього стилю, так і з ангелологією. За етнографічними даними відомо, що кахлі з сакральними сюжетами, на відміну від кахель звичайного (ординарного) типу, ніколи повністю не заповнювали дзеркало печі, а зазвичай розміщувалися поодинокими вставками по кутах цокольної частини печі, під iii увінчуючим карнизом та на завершенні. Отже, у складі одного пічного гарнітуру такі кахлі були присутні у невеликій кількості.

Це, власне, й пояснює нечисленність зразків кахель даного типу у складі археологічних колекцій й певну унікальність знахідок.

Одна із знахідок сакральної кахлі на території Києво-Печерської лаври, походить з розкопок 1993 р. в районі Трапезної палати ${ }^{7}$. Це фрагмент полив'яної кахлі XVI ст. (зелена глазур) 3 пластиною за розмірами 13,5 (неповний) х 14,5 см. Пластина декорована рельєфом зображення двокрилого ангела 3 книгою у руках (рис. 5.1). Ще один невеликий фрагмент коробчастої кахлі 3

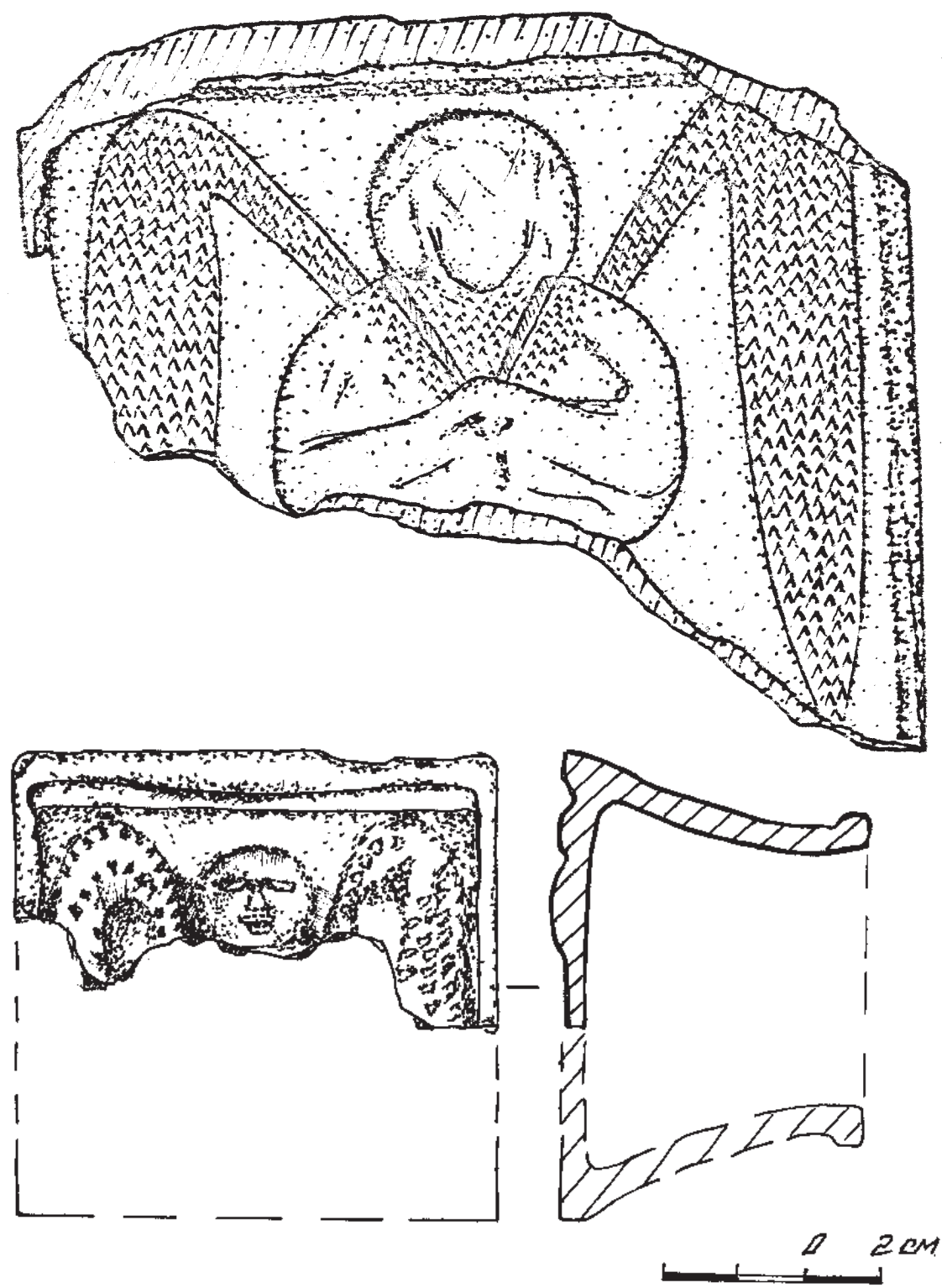


${ }^{8}$ Балакін, С. А., Оногда, О. В. (2008) Археологічні матеріали з розкопок Печерської гауптвахти. Праці центру пам'яткознавства, (13), 123-144.

${ }^{9}$ Харламов, В.А. (1985) Отчет архитектурно-археологичекого отряда Киевской археологической экспедиции АН УССР об археологических исследованиях памятника древнерусской архитектуры нач. XII в. Трапезной Киево-Печерского монастыря, проведенных в 1985г. НА IA НАНУ, (1985/296).

${ }^{10}$ Колупаєва, А. (2006) Українські кахлі XIV-XX ст. Львів: б. в., 86-94.
Рис. 6.1. Кахля XVI ст. 3 рельєфним зображенням старця рельєфним декором у вигляді зображення ангела було виявлено під час досліджень 2015 р. у корпусі №4. Це частина від неполив'яної кахлі XVI ст. (розміри зазначеного фрагмента - 13,0 х 6,5 см; товщина черепка - 0,4 - 0,8 см; висота рельєфу 0,5 - 0,6 см; висота румпи - 8,5 см). Пластину виробу з одноступінчатою рамкою декоровано фігурою ангела, виконаною у високому рельєфі (рис. 5.2).

Такий різновид виробів, як кахлі з портретним зображенням у колекції пічної кахлі КПЛ представлені поодинокими знахідками, одну з яких було отримано під час археологічних досліджень Печерської гауптвахти 1988 р. ${ }^{8}$. Це частина полив’яної кахлі 3 рельєфним зображенням старця та написом “СИЛНІ”. Розміри фрагмента складають 12,0 х 12,0 см (рис.6.1). Про ще одну кахлю відомо з архівних джерел, знахідка походить з розкопок Трапезної церкви у 1985 р. Мова йде про майже повну форму неполив’ яної кахлі XVI ст., з рельєфним портретом жінки 9 .

Кахля з тератологічним декором також входить у склад колекції. Присутність виробів такого типу у монастирських келіях можна пояснити завдяки трактуванню символіки сюжетів й їхньої популярності у кахлярстві XVI - XVII ст. регіонах Середнього Подніпров'я. Зображення лева 3 розкритою пащею, з висунутим язиком - це символ сили та влади. Гріфон у мистецтві середньовіччя дуже розповсюджений персонаж - символ двоякої природи Христа, символ перемоги над злом ${ }^{10}$.

Серію знахідок пічної кахлі XVI - XVII ст., з тератологічними зображеннями було отримано під час археологічних досліджень

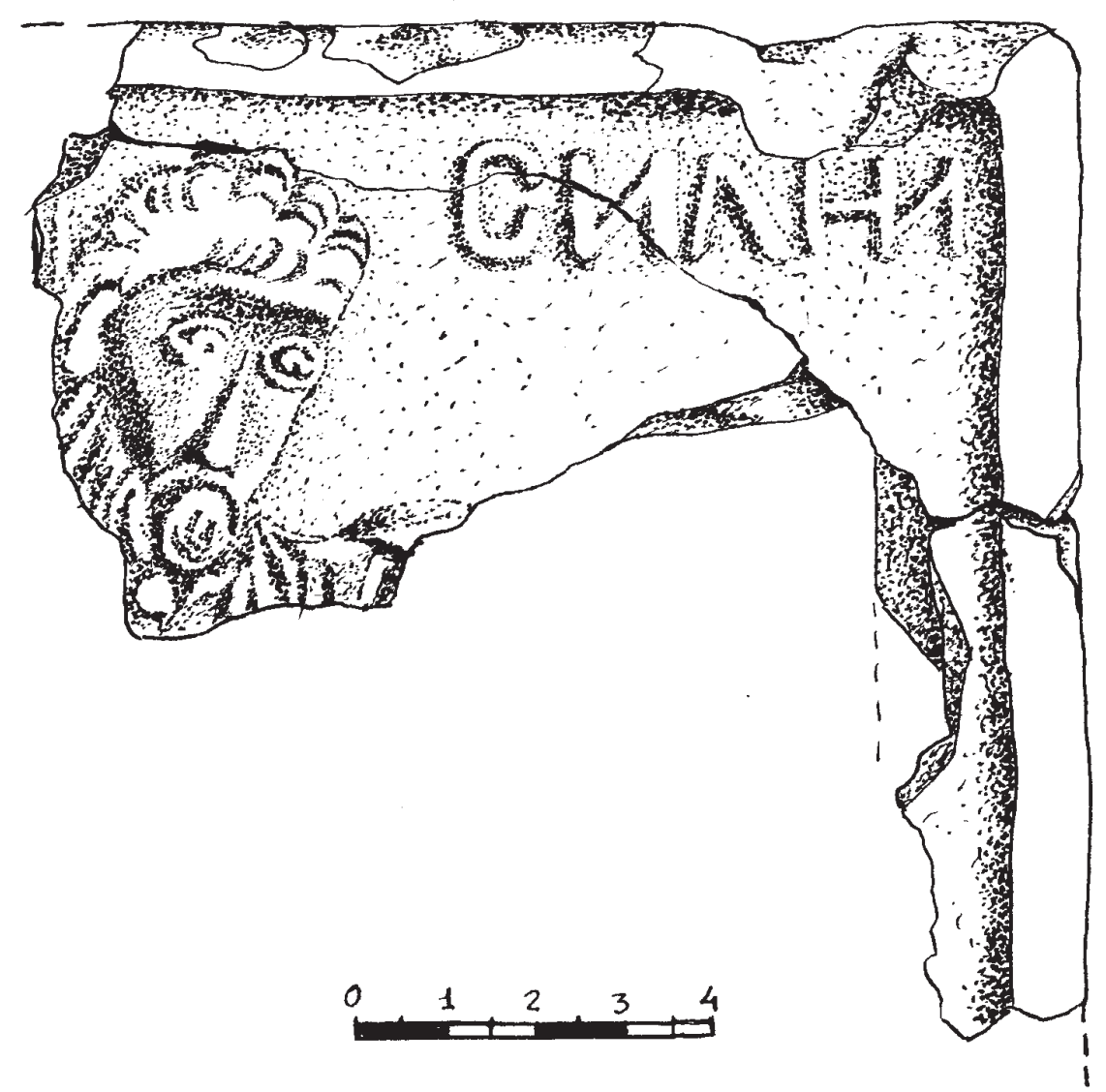


Рис. 7.1, 7.2. Кахлі XVII ст. 3 тератологічними зображеннями.
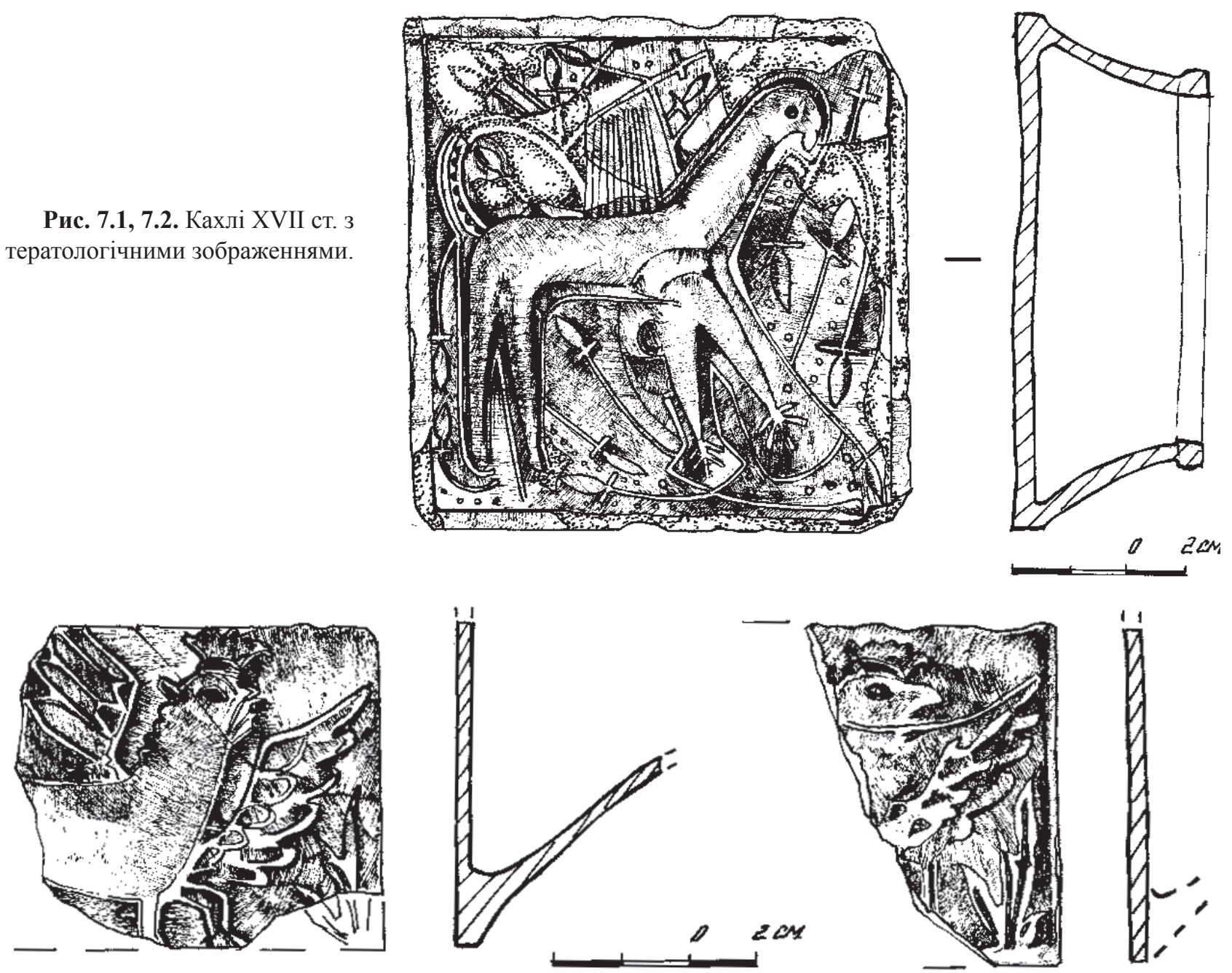

${ }^{11}$ Фінадоріна, Д.В. (2016) Нова колекція кахель $з$ території верхньої лаври. Могилянські читання $2015 \mathrm{p}$.
2015 р. у східній секції корпусу №4. Зазначені вироби суттєво поповнили склад колекції кахлі КПЛ за даною унікальною групою ${ }^{11}$.

Однією зі знахідок є майже повна форма лицевої полив'яної виповнюючої кахлі з вузькою одноступінчатою рамкою, пластину якої декоровано рельєфним зображенням міфічної тварини та супутніми дрібними елементами у вигляді стилізованих (колосків або травинок) ліній, крапок. Міфічну тварину виконано у високому рельєфі, вона має чотири лапи з кігтями, вузьку витягнуту шию, голову з дзьобом, закручений хвіст. Розміри пластини кахлі - 17,5х17,5 см; товщина черепка - 0,5 - 0,8 см; висота рельєфу 0,1 - 0,4 см; висота румпи - 5,5 см; глазур зеленого кольору (рис.7.1). Кахля з таким зображенням трапляється серед відомих нам пічних виробів Києва вперше.

Серед цього ж матеріалу, присутні зразки кахлі з зображеннями “грифона" (три фрагмента коробчастої пояскової кахлі 3 полив' яною поверхнею). Декор пластини виконано в невисокому рельєфі у вигляді міфічної тварини з крилами. Розміри пластини - 10,0 х (неповний розмір) см; товщина черепка - 0,5 - 0,7 см; висота рельєфу $0,1 \mathrm{~cm}$; румпу втрачено, глазур зеленого кольору (рис. 7.2).

Ще один різновид “тератологічної кахлі” представлено зразком $з$ рельєфним зображенням лева. Такі кахлі у колекції Киє- 
Puc. 8.1, 8.2. Кахлі XVI ст. 3 зображенням лева.
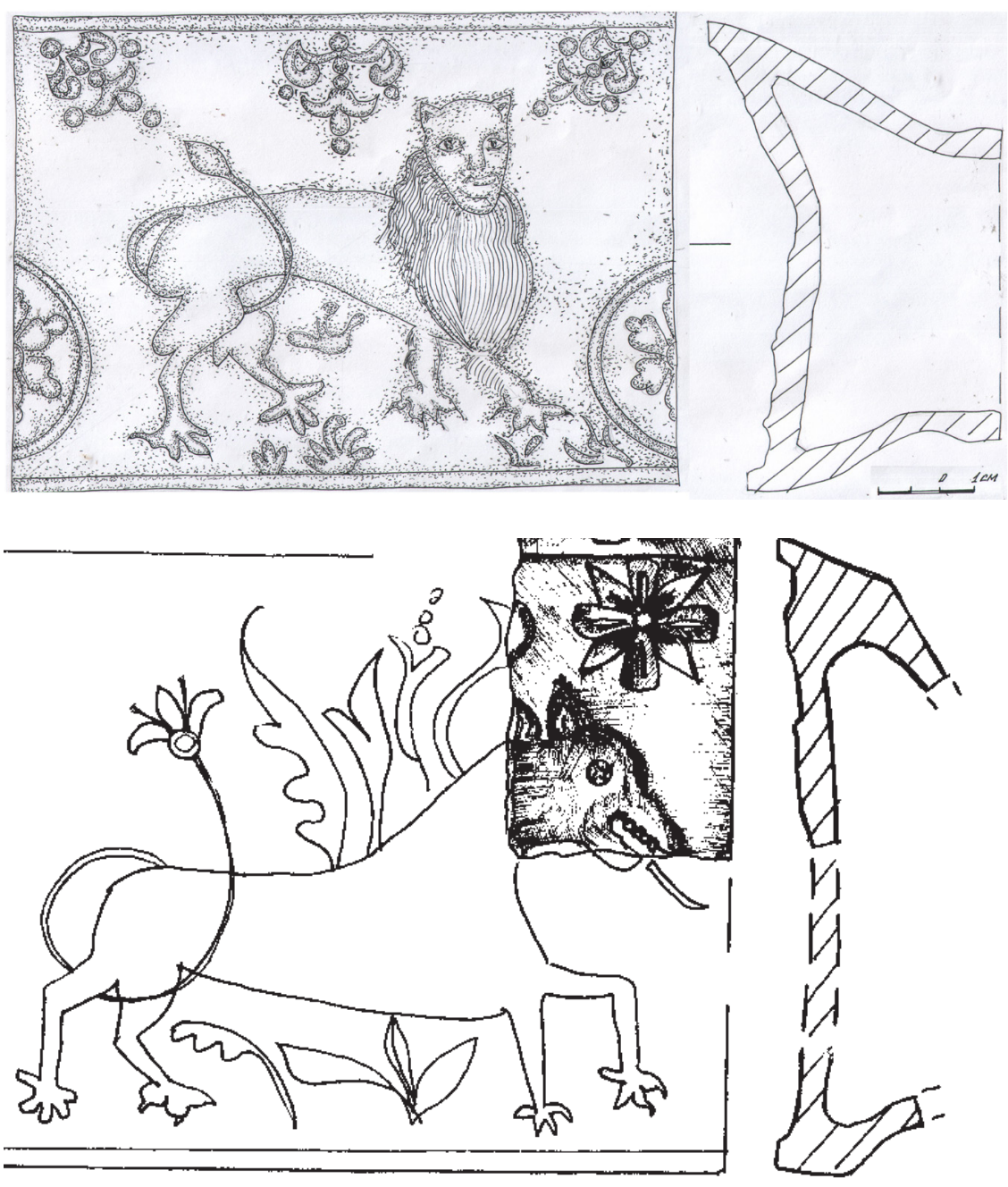

во-Печерського заповідника є як з примітивним виконанням даного сюжету, так й з чітко проробленими деталями рельєфу.

Найбільш яскравими серед них можна виділити кахлю з розкопок на вул. Цитадельній 1987 р. Це лицьовий полив'яний виріб XVII ст., з увігнутою прямокутною пластиною, декорованою зображенням стилізованого лева та рослинно-геометричними елементами. Розміри пластини: 21,5 х 15,3 см, висота румпи - 10,0 см; полива зеленого кольору (рис. 8.1). Та кахлю з території Києво-Печерської лаври, яка $є$ аналогом вище наведеного виробу, але виконану у поліхромному варіанті. Також два фрагмента 3 зображенням лева було отримано 3 розкопок у східній секції корпусу №4 КПЛ. Один з них від полив’яної кахлі (глазур зеленого кольору), інший від кахлі з теракотовою поверхнею (рис. 8.2).

До цієї ж групи кахель кінця XVII ст. $з$ колекції Києво-Печерського заповідника належать вироби з декором у вигляді солярних мотивів. Маються на увазі кахлі з розкопок Верхньої Лаври (корпус № 4, 2015 р.). Це фрагменти кахель з солярними знаками, виповнені в двох варіантах, 3 полив'яною та неполив'яною поверхнями (виявлені фрагменти від трьох окремих форм). Композиція декору - центрична, чотирьохчастинна, складена 3 наступних стилізованих елементів: ромб з сонцем, поєднання символу луни 3 “вогневим колесом", вигнуті листя рослин. Розміри пластини пов- 
них виробів складають - 20,0 х 20,0 см; румпу втрачено (рис. 9.1). Подібну кахлю, але $з$ деякими відмінностями у елементах орнаменту, виявлено біля корпусу № 39, ділянка саду біля Ближніх печер, розкопки 2007 р. (рис. 9.2).

Незрівнянно більшу групу складають вироби XVII - XVIII ст. Кахля зазначеного періоду характеризується максимально повною репрезентативністю як у плані типологічних різновидів, так і в плані стилістичних варіантів оздоблення виробів. Зазначимо, що дана хронологічна група кахель відрізняється від своїх попередників усталеними морфологічними параметрами. Розміри лицьових пластин виповнюючих кахель коливаються від 18,5х20,0 до 21,0х21,0 см, кутових кахель - від 18,5х18,5 до 21,0х21,0 cм (для лицевої пластини) та 18,5-21,0x9, 5 см (для бокової). Висота румпи варіює від 8,5 до 10 см. Декор кахель XVII - XVIII ст. переважно рослинного та рослинно-геометричного типу. Тенденція того часу, до рівномірного заповнення площини кахлі обумовила

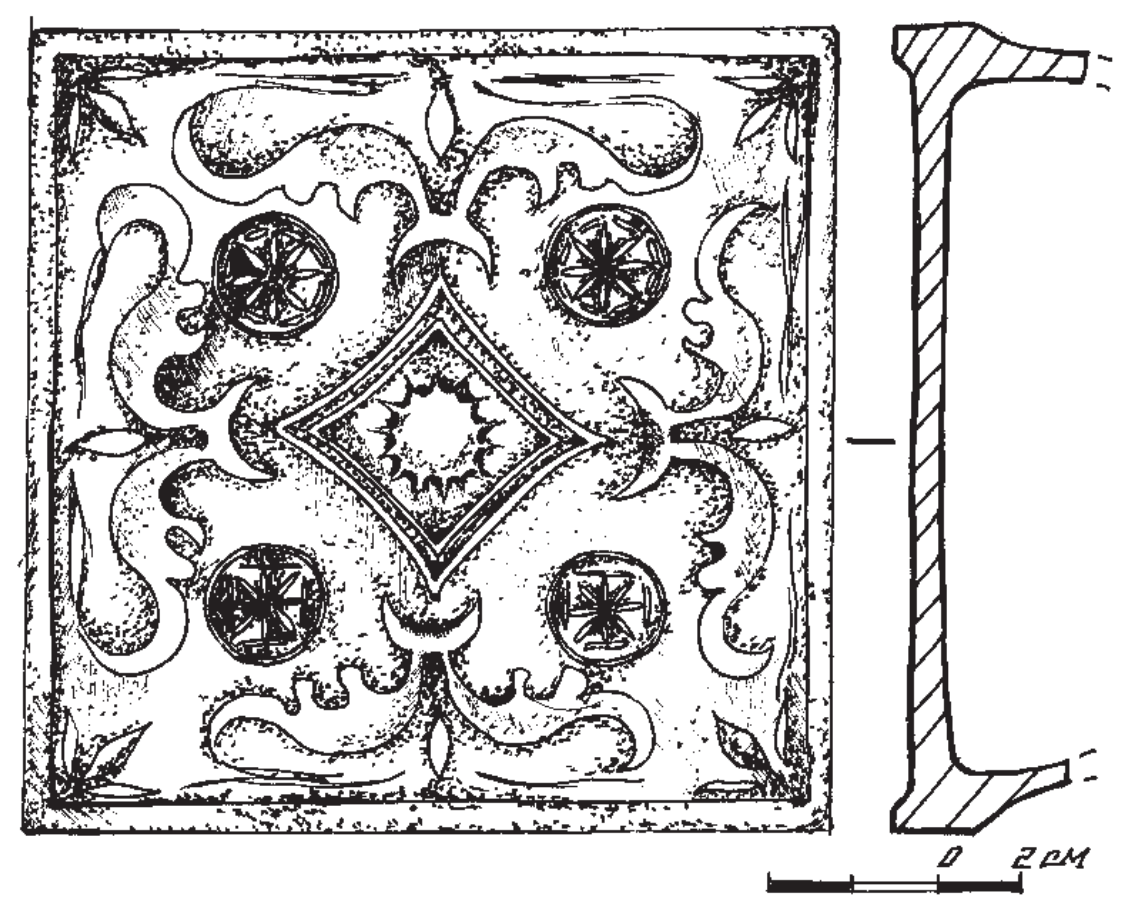

Puc. 9.1, 9.2.

Кахлі XVII ст. 3 солярними мотивами.

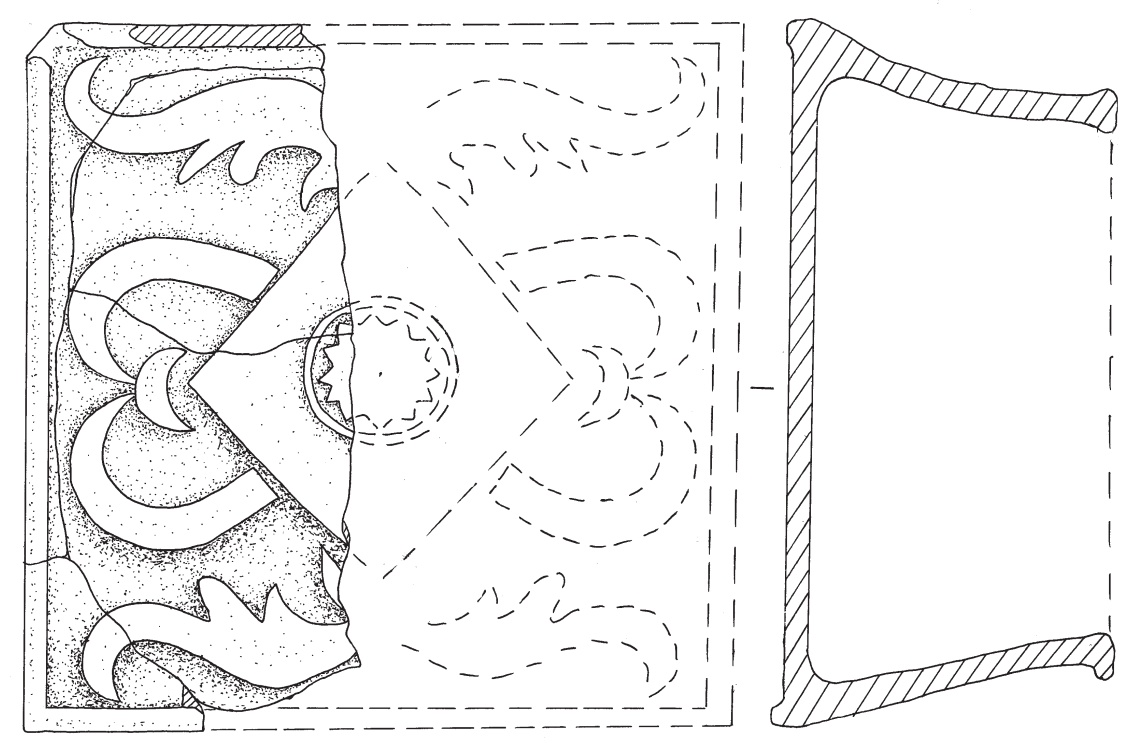


${ }^{12}$ Виногродська, Л. І. (1998) До історії розвитку кахлярства в Україні у XIV-XVII ст. В Історія Русі-України, cc. 265-272.

${ }^{13}$ Фінадоріна, Д. В. (2011) Типологічні подібності пічної кахлі Печерського та Вознесенського монастирів XVII ст. Нові дослідження пам'яток козачької доби в Украӥні. (20), 178-183. в орнаменті кахель ряд нових схем, в основі яких лежало застосування вісної симетрії. Найпоширенішою і типовою стала осьова чотиричленна композиція з означеним центром, побудована на взаємно перпендикулярних перехрещених діагоналях або осях, паралельних сторонам кахлі. У першій половині XVII ст. відома й дзеркально-симетрична структура - 'вазон". Ще одним різновидом декорувань кахель, стає сітчаста композиція "'з рельєфними перетинками". До того ж орнамент кахель характеризується більш поглибленними стилізаціями, окремі рослинні мотиви набувають геометричних форм. На них чіткіше прочитуються вісі, хрещати фігури, з'являються характерні мотиви: серцеподібні, ліроподібні, а також композиція у вигляді чотирьох пар сплетених кілець ${ }^{12}$. Більша частина кахель 3 фондової колекції Києво-Печерського заповідника має прямі аналоги серед подібних знахідок жіночого Вознесенського монастиря ${ }^{13}$.

Наведемо найбільш презентабельні та характерні зразки кахлі XVII - XVIII ст., за типологічним різновидом орнаментального декору.

Однією з найпоширеніших знахідок пічної кахлі Києво-Печерської лаври є кахля з орнаментом у вигляді восьми переплетених кілець та квіткою у центрі композиції (рис. 10.1). Кахля про яку йдеться, походить з наступних об'єктів Заповідника: знахідки 2007 р., корпус №39 (вісімнадцять лицевих виповнюючих кахель, та одна кутова виповнюючи кахля з неполив'яною поверхнею); 2001 р., корпус №3 (лицева виповнююча, вкрита поливою брунатного кольору); розкопки 1987 р., Воскресенська церква (дві кутові неполив'яні виповнюючі); археологічні дослідження 2015 р., корпус 4 (фрагменти від кутової та лицевої виповнюючих полив' яних кахель - полива зеленого кольору, фрагмент від кахлі з неполив'яною поверхнею); у 1987 р., вул. Цитадельна, яма №2 (фрагмент лицевої виповнюючої неполив'яної кахлі). У переважній більшості це неполив'яні кахлі, але $\epsilon$ й поодинокі знахідки виробів вкритих поливою зеленого, брунатного кольорів. Розміри пластин лицьових кахель коливаються від $18,5 \times 18,5$ до $20,0 \times 20,0$ см, розміри кутових кахель становлять $18,5 \times 18,5$ і 20,0×20,0 см та $18,5-$ $20,0 \times 9,5$ см. Висота румпи виробів - від 8,5 до 9,5 см.
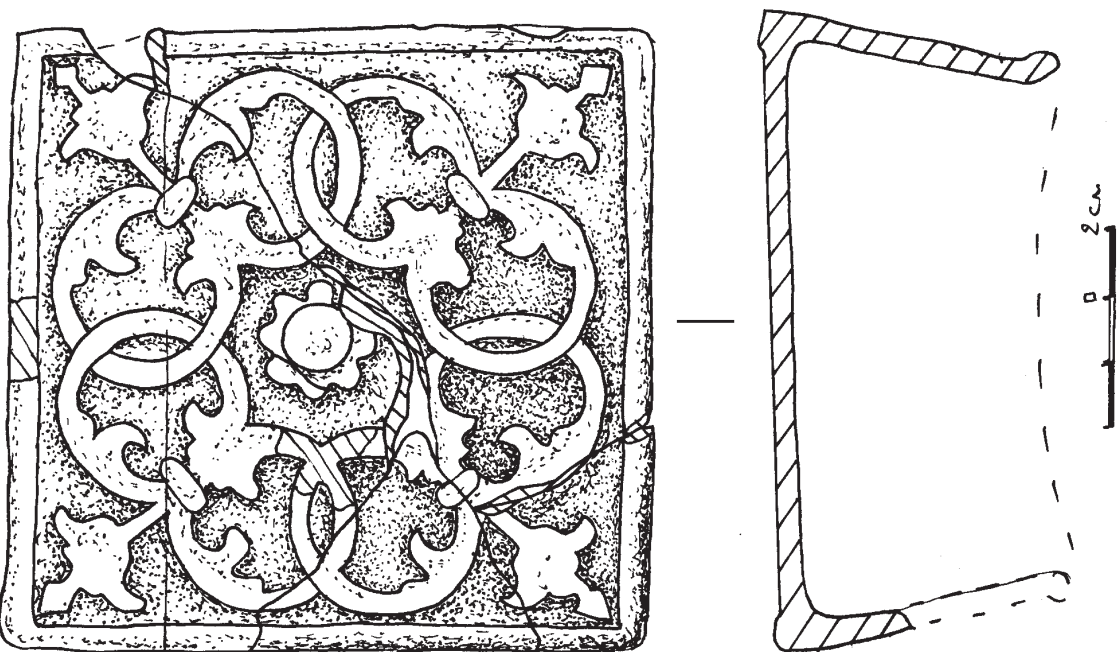
Описана веще кахля представлена в колекції й в більш ранній варіації виконання цього мотиву. Маються на увазі вироби, пластину яких декоровано орнаментом з композицією, складеною 3 невеликого опуклого кола, від якого до кутів пластини відходять стилізовані стебла рослин 3 пікоподібним завершенням. Розміри пластини кахлі складають - 18,5×18,5 см; висота румпи - 11,0 cм, поверхня вкрита поливою зеленого кольору (рис. 10.2). Знахідки походять з розкопок 2007 р., корпус № 86 та корпус № 39. Також близька за побудовою орнаментальної композиції до вище представлених виробів кахля з рослинно-геометричним декором у вигляді “сонечка”. Походить 3 археологічних об'єктів Верхньої лаври (розкопки 2007 р. біля корпусів №№ 3, 39). Центральний елемент декору - маленьке “сонечко”, у обрамлені стилізованої рослини 3 паростками - трилисниками. Вироби неполив'яні, лицеві виповнюючи, за розмірами пластини $-18,5 \times 18,5 \mathrm{~cm}$, висотою румпи до 10,0 см (рис. 10.3).

Як окремий різновид кахлі XVII-XVIII ст. можна виділити вироби, у складі орнаментального декору яких присутні елементи кованого орнаменту.

Як один $з$ таких прикладів - кахлі з мотивом "крину". Зазначений орнамент складається з $\mathrm{S}$-подібних фігур з перетинками (кований орнамент), доповнених стилізованими елементами у вигляді паростків-трилисників, розташованих між кінцевими завит-

Puc. 10.2, 10.3.. Кахлі XVII-XVIII ст. 3 чотирьох частинною композицією.
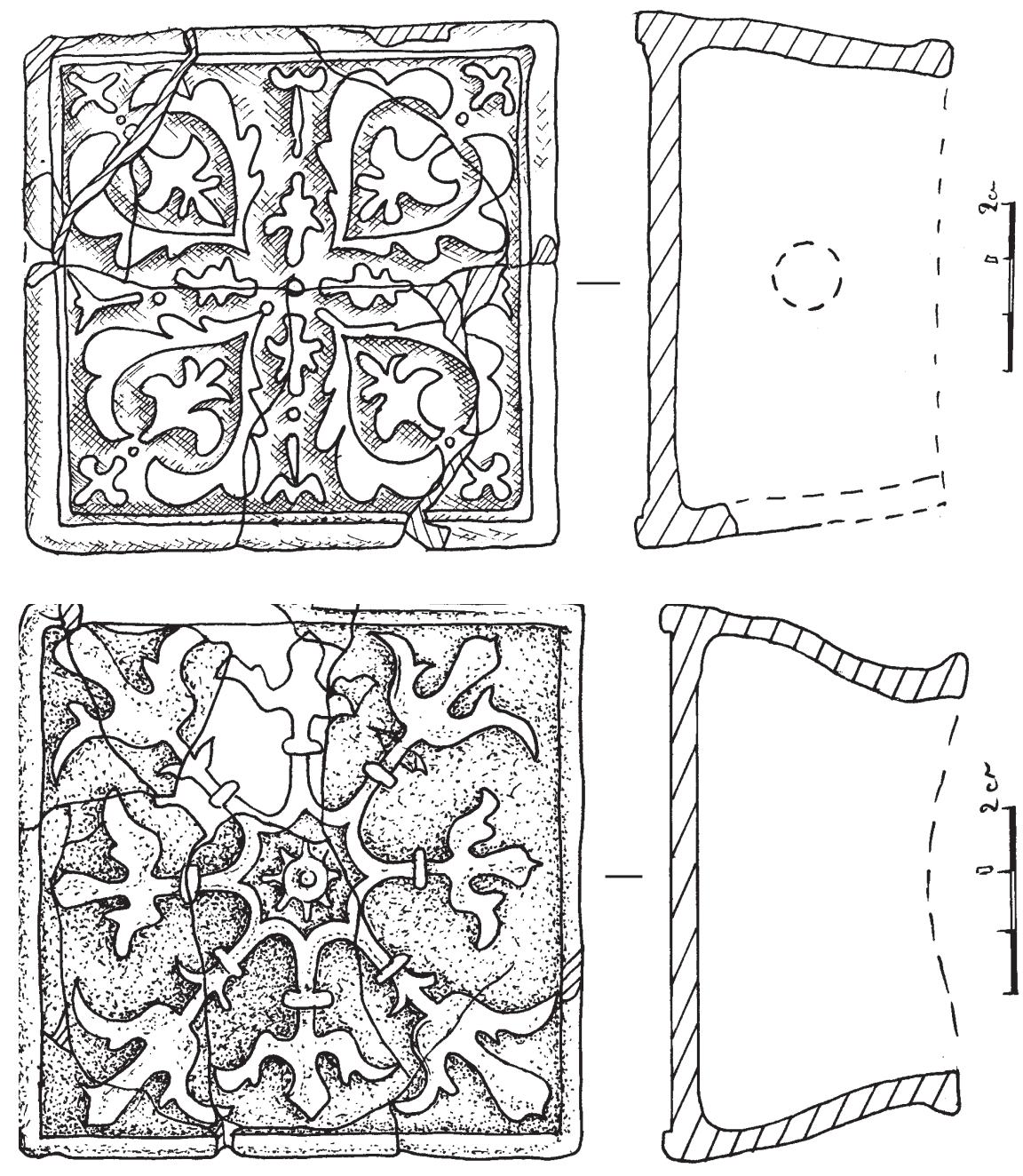
ками фігур. Такі кахлі на території Києво-Печерського монастиря були виявлені під час розкопок на подвір'ї Вознесенської церкви у 1987 р. та у 2001 р. поблизу корпусу № 3. Це лицеві неполив’яні кахлі за розмірами пластини $-21,0 \times 21,0$ см, висотою румпи $-9,0-$ 10,0 см, та карнизні кахлі з пластиною вигнутої форми за розмірами $-20,0 \times 13,0$ см, висотою румпи 9,0 см (рис. 11.1, 11.2).

Також відомі дві лицьові виповнюючи кахлі, у декорі яких елементи “кованого" орнаменту поєднуються 3 так званими “акантовими”. Полив'яний зразок такої кахлі походить $з$ розкопок 1987 р. $з$ вул. Цитадельної. Розміри пластини виробу складають $-22,4 \times 22,4$ см; висотою румпи 11,0 см (рис. 12.1). Аналогічні кахлі у двох технологічних типах - 3 теракотовою та полив'яною поверхнею (зелена полива) знайдені під час досліджень на Оглядовому майданчику КПЛ у 1987 р. Розміри пластин зазначених складають - 22,5×22,5 см, висота румпи - 9,5-11,0 cм.

Серед згаданої групи кахель 3 “кованим орнаментом” походять 3 розкопок 2015 р., корпус № 4, Верхня лавра. Мова йде про полив'яну (глазур зеленого кольору) та теракотову кахлі, декоративна композиція якої складається зі стилізованої квітки, рослинних

Puc. 11.1, 11.2. Кахлі XVII-XVIII ст. 3 мотивом "крину”.
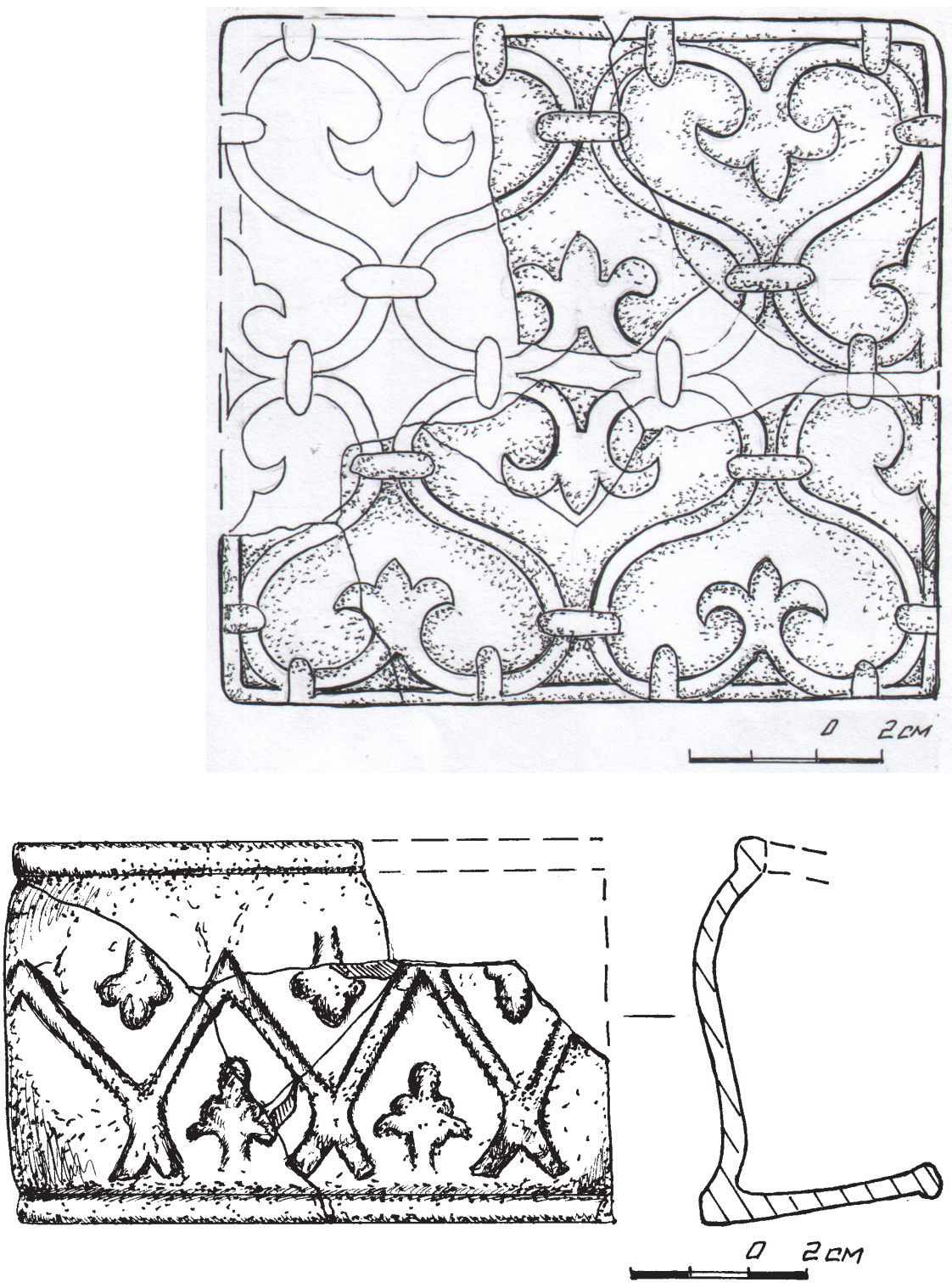
елементів та рельєфних перетинок в стилі кованого орнаменту. Кахля представлена у збірці Києво-Печерської лаври з теракотовою та з полив'яною поверхнею. Розміри пластини згаданих виробів $-17,5 \times 17,5$ см; висота румпи - 10,0 см. Неполив'яний варіант аналогічної кахлі було виявлено під час дослідженні ділянки саду Ближніх печер поблизу корпуса № 39 у 2007 р. (рис. 12.2).

Далі розглянемо кахлі з “килимовим орнаментом”. Побудова їхньої декоративної композиції розрахована на продовження зображення при поєднанні з іншими кахлями (як по горизонталі, так і по вертикалі). На території Києво-Печерського заповідника вищезгадані вироби даного типу походять 3 археологічних розкопок Верхньої лаври 1992, 2001 рр. Це лицьові виповнюючі кахлі 3 теракотовою та полив'яною поверхнею, декоровані килимовим орнаментом рослинно-геометричного типу. Орнамент складається зі скріплених між собою складних хрестоподібних фігур, 3 вписаними у них стилізовано-рослинними елементами. Розміри

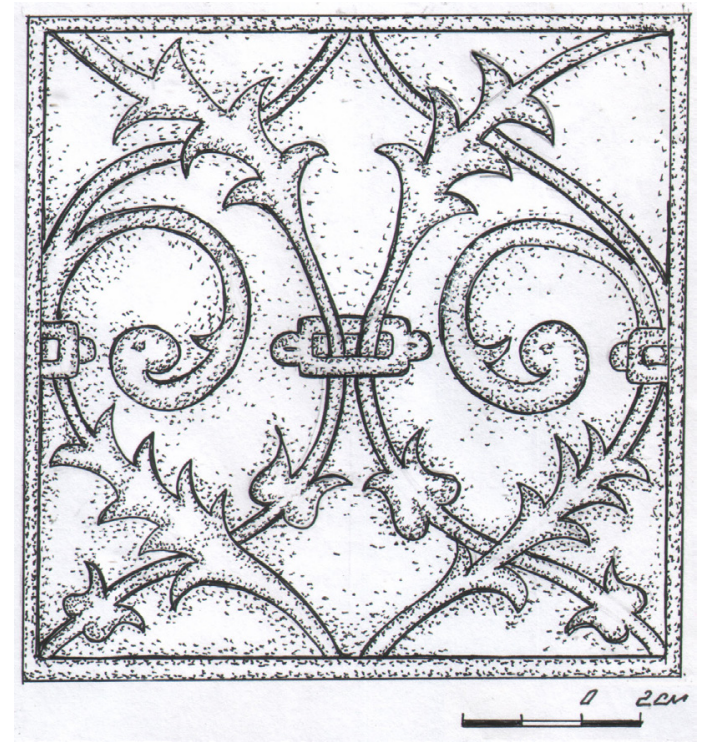

Puc. 12.1, 12.2. Кахлі XVII-XVIII ст. з елементами “кованого орнаменту”.
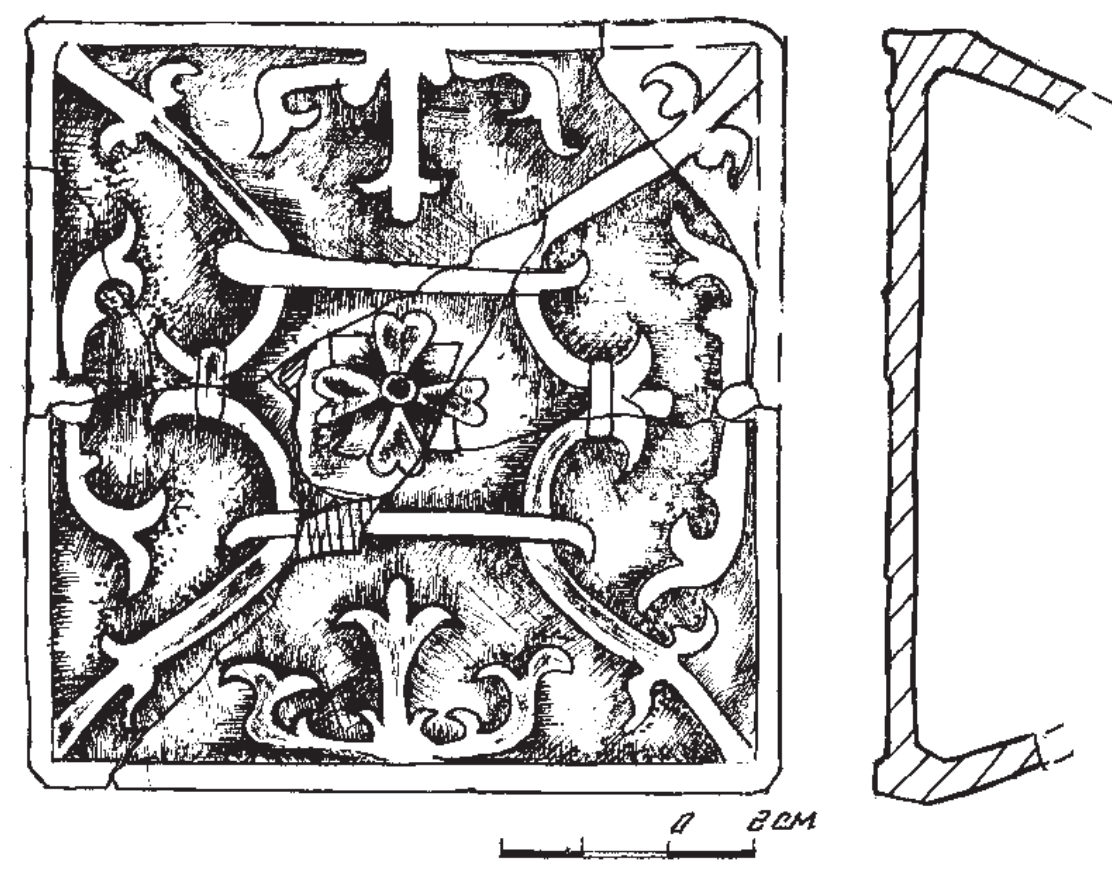
${ }^{14}$ Гущина, Л. В., Фінадоріна, Д. В. (2009) Про одну групу мальованих кахель XIX ст. 3 фондів НКПІКЗ.

Нові дослідження пам'яток козацької доби в Україні. (18), 80-84.
Puc. 13.1, 13.2. Кахлі XVII-XVIII ст. 3 “килимовим орнаментом". пластин виробів становлять 20,0×20,0 см, висота румпи - 9,0 см. Серед полив'яних кахель трапляються як монохромні (зелена або бордова полива), так і поліхромні вироби із застосуванням глазурі білого, салатового, жовтого та синього кольорів (рис. 13.1). Ще одним прикладом кахлі з “килимовим” орнаментом $є$ знахідка лицевої виповнюючої кахлі, яка походить з розкопок 2007 р. біля корпусу № 39. Кахля має розміри пластини $-21,0 \times 21,0$ см; висоту румпи $-10,0$ см. Виріб декоровано килимовим орнаментом складеним з геометричних елементів, ромбів-зірок та перехрещених ліній (рис. 13.2).

Також серед колекції кахлі в Києво-Печерського заповідника XVII-XVIII ст. представлені вироби з рослинним декором. Одні 3 них - карнизні кахлі з “дубовим листям" походять з розкопок 2007 р. проведених поблизу корпусів №№ 39, 36. Це чотири карнизні кахлі за розмірами вигнутої пластини $18,0 \times 13,0$ см і висотою румпи у 9,0 - 13,0 см, серед них є як полив'яні, так і неполив'яні екземпляри (рис. 14.1).

I як завершальний етап розвитку українського кахлярства у колекції КПЛ представлено кахлі XIX ст. ${ }^{14}$. Кахлі цього періоду
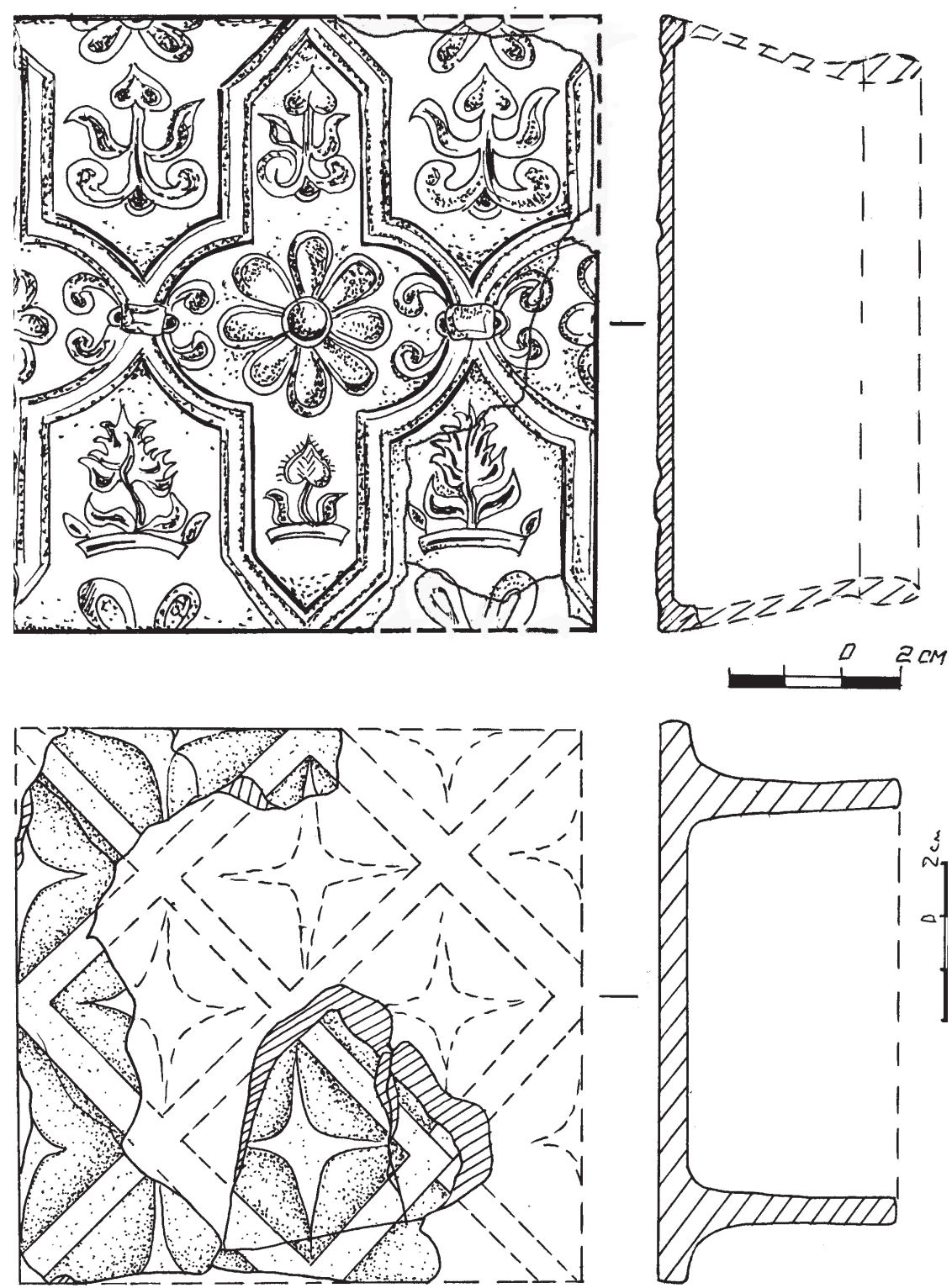


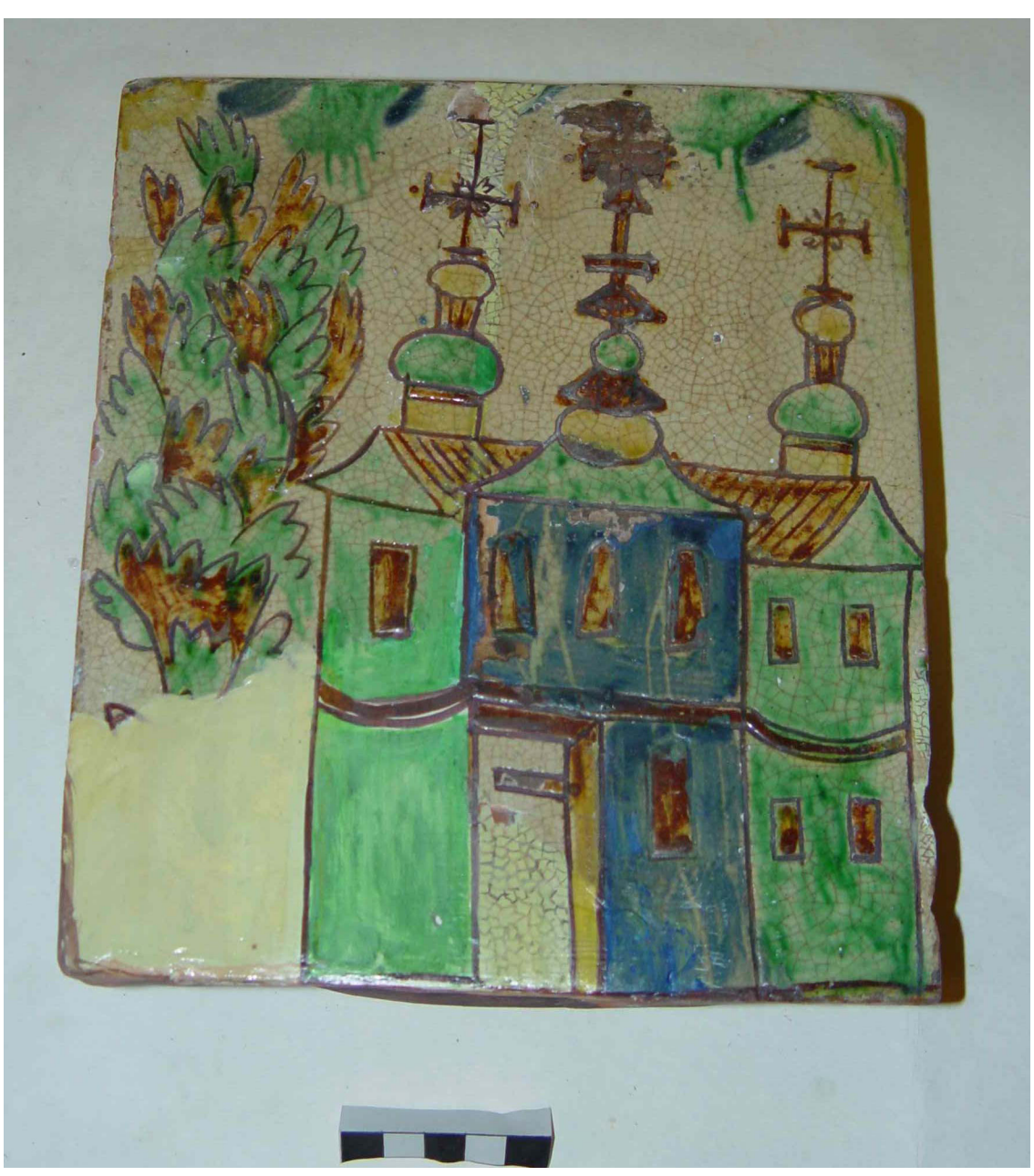

Puc. 15.1.

Кахля ХІХ ст.

3 сюжетними зображеннями.

представлені переважно полив'яними поліхромними виробами, лицьову поверхню яких декоровано із застосуванням технік ріжкування, ритування та фляндрівки. Тематика декоративного оздоблення досить різноманітна і включає зображення архітектурно-релігійного, сюжетного та рослинно-геометричного типу. Розміри пластини виповнюючих лицьових кахель коливаються від 23,5×16,2 см до 22,0×14 см. Висота румпи - від 5,0 до 6,0 см. Довжина пластини кутових кахель становить 22,5 см, ширина варіює від 3,5 до 14,0 см. Висота румпи не перевищує 5,0 см. Розміри пластини карнизних профільованих кахель $-22,5 \times 9,7$ см, висота румпи - 5,5-7,0 см. Значну кількість таких виробів виявлено у 1981 р. на території Верхньої лаври, між корпусами № 4 та № 21-а також у 2001 р. під час археологічних досліджень біля корпусу №21-а. Збірка мальованих поліхромних кахель XIX ст. містить зразки лицьової, кутової та бордюрної кахлі. Серед цієї групи кахель, особливо цікавими $є$ дві знахідки, а саме лицьова кахля із зображенням церкви (рис. 15.1) та кутова кахля з силуетом людини (рис. 15.2).

У композиційному плані “архітектурна” кахля складається 3 двох зображень - трибанної церкви 3 притвором, розміщеної у правій частині виробу і стилізованого дерева 3 лівого боку церкви. Зображення виконані на світло-жовтому "мармурованому" тлі ангобами брунатного, синього і жовтого кольорів та зеленою поливою. 
Puc. 15.2.

Кахля XIX ст.

3 сюжетними зображеннями.

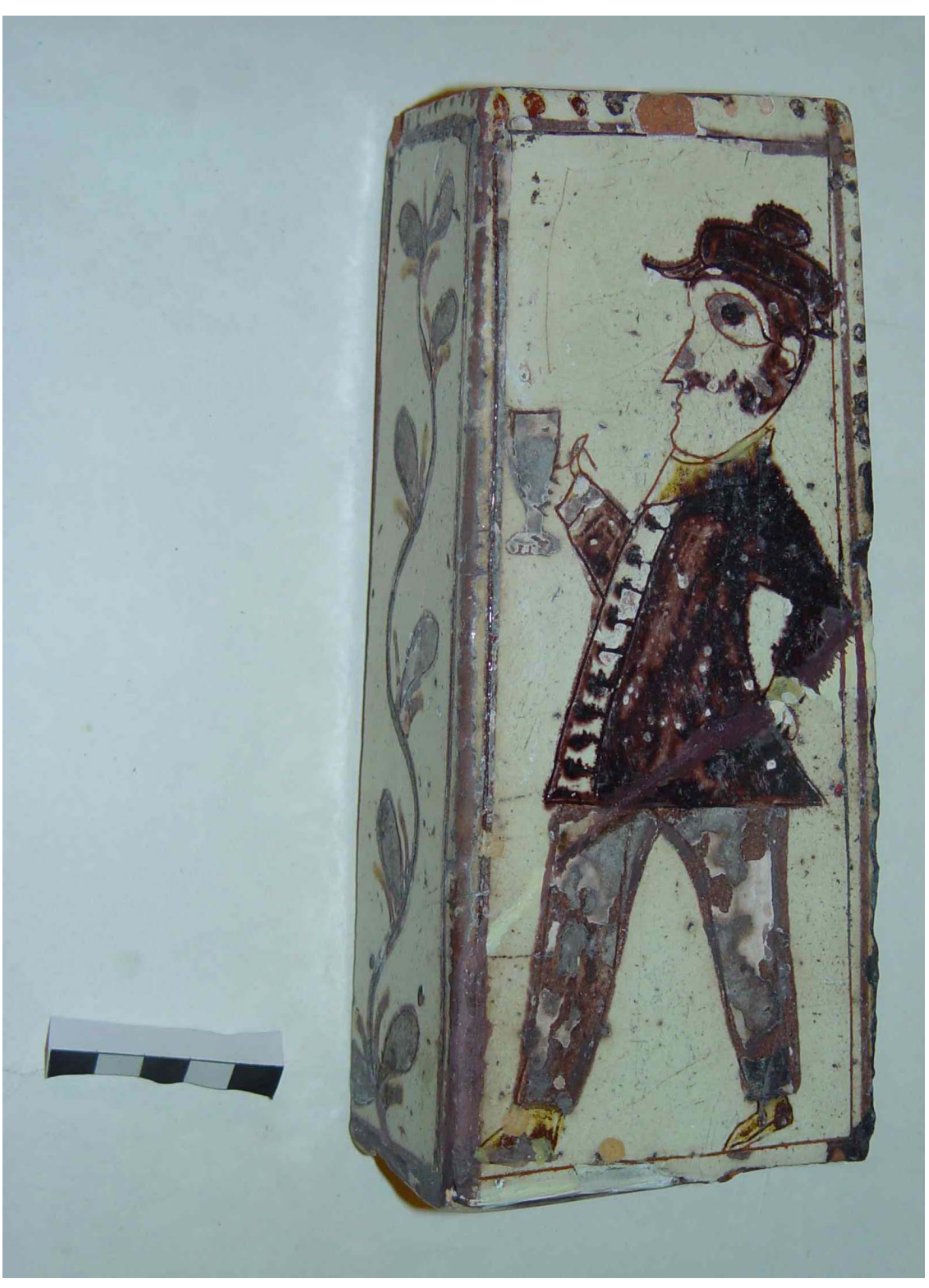

Зовсім протилежна за сюжетом кутова виповнююча кахля 3 зображенням людської постаті. На білому тлі лицьової пластини зображено в профіль чоловічу постать. Розкута, театралізована поза молодого чоловіка передає жанровий характер зображення. Бічна сторона кахлі орнаментована хвилястою “галузкою" з плодами та листям в жовто-брунатній кольоровій гамі.

Таким чином, у складі збірцки пічної кахлі Києво-Печерської лаври, яка складається приблизно з 600 одиниць (повні форми та фрагменти), можна виділити близько 70-90 виробів кахель, як окремих прикладів за типологічними та морфологічними ознаками. Відзначимо, що розглянута колекція археологічної кахлі репрезентує всі основні декоративні різновиди, притаманні для української пічної кераміки XV-XVIII ст. Рання кахля - горщикоподібна та кахля 3 “пуклею” представлені поодинокими екземплярами. Найбільш численними й показовими у колекції $є$ вироби кінця XVI-XVIII ст. По-перше, це серія знахідок ранніх плиткових кахель XVI-XVII ст., з сюжетом декору, переважно сакрального, міфологічного, змісту (з антропоморфними, тератологічними зо- 
браженнями та елементами давньоруської символіки). По-друге, кахлі XVII-XVIII ст., з орнаментальним декором, переважно рослинного й рослинно-геометричного типу. Завершальний етап розвитку українського кахлярства у колекції КПЛ ілюструють вироби XIX ст. Це переважно полив'яні поліхромні кахлі з орнаментальним декором рослинного, сюжетного типів, виконаного у техніках ріжкування, ритування та фляндрівки.

У даній роботі ми представили найбільш яскраві та показові зразки пічної кахлі XVII-XVIII ст. з території Києво-Печерського монастиря з кожної хронологічної та типологічної групи, з деякими прикладами їх аналогів з синхронних пам'яток Печерську. Цей масив матеріалу заслуговує всебічного наукового опрацювання $\mathrm{i}$ може включати у себе декілька окремих аспектів. Один з них, наприклад, може полягати у спробі максимально чіткої хронологічної диференціації зібраних кахель, “прив'язки” їх груп до певних етапів монастирської історії чи конкретних господарсько-побутових об'єктів монастирської структури. До того ж, треба зауважити, що знахідки колекції наразі перебувають у різному стані збереженості. Більшість виробів потребують консерваційно-реставраційних заходів, за умови виконання яких колекція може стати повноцінною музейною збіркою каталогу пічної кахлі XV-XIX ст.

\section{REFERENCES}

Vynohrods'ka, L. I. (1997) Do istoriyi keramichnoho ta sklyanoho vyrobnyctva na Ukrayini u XIV-XVIII st. Arkheolohiya. (2), 129-142.

Kolupayeva, A. (2006) Ukrayins'ki kahli XIV-XX st. L'viv: b. v., 77-88.

Ivakin, H. Yu., Balakin, S. A. (2001) Deyaki pidsumky arkheolohichnyh doslidzhen' na terytoriyi Kyevo-Pechers'koyi lavry u 2000 r. Mohylyans'ki chytannya. (3), 126-135.

Ivakin, H. Yu. (1996) Istorychnyj rozvytok Kyeva XIII - seredyny XVI st. K.: b. v., 87.

Onohda, O. V. (2008) Keramichni kompleksy XIV - XVI stolit' z rozkopok na terytoriyi staroho arsenalu. Lavrs'kyj al'manakh. (21), 24-31.

Balakin, S.A. (2002) Zvit pro rezul'taty arkheolohichnykh doslidzhen' na terytoriyi Nacional'noho Kyevo-Pechers'koho istoryko-kul'turnoho zapovidnyka u 2001 r. K.: KPL - A - NDF, (688)

Balakin, S.A., Zazhyhalov, O.V., Finadorina D.V. (2015) Zvit pro rezul'taty arkheolohichnykh doslidzhen' na terytoriyi Nacional'noho Kyevo-Pechers'koho istoryko-kul'turnoho zapovidnyka u 2015 r. K.: KPL - A NDF, (731)

Ykonohrafyya anhelov y arkhanhelov. Avaliable from: http://www.angelologia.ru/iconographia/183_ikonografia_angelov.htm. [Accessed May 14, 2016].

Balakin, S.A. (2008) Trapezna cerkva ta palata Pechers'koho monastyrya (arkheolohichnyj aspekt). Novi doslidzhennya pam 'yatok kozac'koyi doby v Ukrayini. (17), 41-48.

Balakin, S. A., Onohda, O. V. (2008) Arkheolohichni materialy z rozkopok Pechers'koyi hauptvakhty. Praci centru pam'yatkoznavstva. (13), 123144.

Kharlamov, V.A. (1985) Otchet arxytekturno-arxeolohychekoho otryada Kyevskoj arxeolohycheskoj ekspedycyy AN USSR ob arkheolohycheskykh yssledovanyyah pamyatnyka drevnerusskoj arkhytektury nach. XII v. Trapeznoj Kyevo-Pecherskoho monastyrya, provedennyh v 1985 h. NA IA NANU, (1985/29b) 
Kolupayeva, A. (2006) Ukrayins'ki kahli XIV-XX st. L'viv: b. v., 86-94.

Finadorina, D.V. (2016) Nova kolekciya kahel' z terytoriyi verkhn'oyi lavry. Mohylyans 'ki chytannya $2015 \mathrm{r}$.

Vynohrods'ka, L. I. (1998) Do istoriyi rozvytku kahlyarstva v Ukrayini u XIV-XVII st. In Istoriya Rusi-Ukrayiny, pp. 265-272.

Finadorina, D.V. (2011) Typolohichni podibnosti pichnoyi kahli Pechers'koho ta Voznesens'koho monastyriv XVII st. Novi doslidzhennya pam 'yatok kozac'koyi doby v Ukrayini. (20), 178-183.

Hushhyna, L. V., Finadorina, D. V. (2009) Pro odnu hrupu mal'ovanykh kahel' XIX st. z fondiv NKPIKZ. Novi doslidzhennya pam 'yatok kozac'koyi doby v Ukrayini. (18), 80-84.

\section{Глосарій}

Ангелологія - предметом ангелології, як богословської дисципліни є походження і природа ангелів, їх місце і роль у складі небесного воїнства, ангельська ієрархія і тому подібне.

Антропоморфні зображення - уподібнення будь-чого до людини або перенесення і1і фізичних та інтелектуальних властивостей на тварин, рослини, речі та явища навколишнього світу.

Виповнюючі кахлі - кахлі для виповнення площин стінок печі (фасадні).

Квадрифолій - архітектурний, орнаментальний елемент у вигляді хреста, вкомпонованого у квадрат.

Пояскові кахлі - кахлі для викладання горизонтальних поясків, що виділяють основні композиційні частини печі та використовуються для їх ритмічного збагачення.

Ріжкування - техніка керамічного розпису, коли ангоби (кольорові глини) наносять на виріб, користуючись ріжком.

Румпа - коробчатий виступ із зворотного боку кахлі, призначений для іiі закріплення у муруванні печі (при цьому внутрішня частина румпи заповнюється розчином).

Сакральний - священне, присвячене богам, в широкому сенсі все, що, має відношення до божественного, релігійного, небесного, потойбічного, містичного.

Солярні мотиви - елементи орнаменту, пов'язані з культом сонця та небесних світил.

Тератологічний орнамент - тип орнаментації, що характеризується стилізованим зображенням казкових звірів i птахів, тваринних i рослинних мотивів, що химерно переплітаються.

Фляндрівка - техніка розпису по глині ангобами. На попередньо залитий ангобом фон наносяться геометричні лінії по спіралі, а на них в певному порядку наносяться краплі ангобом іншого кольору, вони стікають до центру роботи створюють дивну геометричну картинкувізерунок, як павутиння.

\section{Финадорина Д. В.}

\section{ОБЩАЯ ХАРАКТЕРИСТИКА НАХОДОК ПЕЧНЫХ ИЗРАЗЦОВ КИЕВО-ПЕЧЕРСКОЙ ЛАВРЫ}

Статья посвящзена коллекции печных изразцов, которые происходят из археологических объектов с территории Киево-Печерского историко-культурного заповедника. В ее состав входят печные изделия $X V$-XIX в. включительно. На их примере можно проиллюстрировать важные странищы истории Киево-Печерского монастыря и, в неко- 
торой степени, развитие производства изразияов на Украине в ичелом. Материал представлен по принципу хронологической периодизации в эволюичи изразцьв. Наиболее ранними находками в коллекичии является гориковидные изразцы XV-XVI в. и изразцы с полусферическим внешним изгибом по ичентру пластины. К следующей группе относятся изразцы XVI-XVII в. с декоративным сюжетом преимущественно сакрального, мифологического содержания (с антропоморфными, тератологическими изображениями и элементами древнерусской символики). Наиболее численную группу в коллекиии, о которой идет речь, составляют изделия XVII-XVIII в. Изразиь этого периода характеризуются максимально полной репрезентативностью, как в плане типологических разновидностей, так и в плане стилистических вариантов отделки изделий. Завериающий этап развития производства изразияов на Украине представлен изделиями ХІХв.

В данной работе мы рассмотрели наиболее яркие и показательнье образиы печных изразияов XVII-XVIII в., найденные на территории Киево-Печерского монастыря, из каждой хронологической и типологической группы. Также приведены некоторые примеры их аналогов из синхронных археологических памятников Печерска. Отметим, что этот объем материала заслуживает более детальной научной обработки, одним из аспектов которой, может быть, попытка максимально четкой хронологической дифференцииации собранных изразцов, “привязки” их групп к определенным этапам монастырской истории или конкретных хозяйственно-бытовых объектов монастырской структуры. Такюе следует обратить внимание на разное состояние сохранности находок коллекции, о которой идет речь. Большинство изделий требуют проведения консервационно-реставрационных мероприятий. При условии выполнения которых, коллекция может стать полноценным музейным собранием печных изразиов XV-XIX в. Национального Киево-Печерского историко-культурного заповедника.

Ключевые слова: археологические находки Киево-Печерской лавры, печной изразец, Новое и Новейшее время.

\section{Finandorina D.}

\section{GENERAL CHARACTERISTIC OF THE FINDINGS OF STOVE TILES OF KYIV-PECHERSK LAVRA}

Article is devoted to the collection of stove tiles, originated from archaeological objects on the territory of Kyiv-Pechersk Lavra National Preserve. The collection includes stove units of XV-XIX centuries, which illustrate important aspects of history Kyiv-Pechersk Monastery and partly a history of Ukrainian tiles' industry. The material is structured according to the chronological periodization of tiles' evolution. The earliest findings are pot-like tiles (XV-XVI centuries) and tiles with half-sphere external bend in the center of the base.

Chronologically next group is the series of findings of early tablet tiles XVI-XVII centuries. They are decorated with the sacral or myth stories, anthropomorphic or teratological figures, and element of Ancient Rus 'symbols.

The biggest group is tiles of XVII-XVIII centuries includes a wide range of products of different types and styles. The ending of Ukrainian tiles industry is illustrated by XIX century tiles.

In this article, we worked on the brightest examples of stove tiles from the territory of Kyiv-Pechersk monastery. We also compared them with the synchronic examples from Pechersk.

This data deserves further examining and may include different aspects. One of them is to try to make more clearly chronological differentiation of the 
Мıсто: ІстоРІя, кУльтУРА, суспільство

collection, linking them to the particular periods of monastery's history or to the particular household objects of monastery structure.

It should be mentioned, that the findings needs conservation and restoration. As far as it will be done, the findings could be full museum collection.

Keywords: archaeological finds of Kiev-Pechersk Lavra, stove tiles, Early Modern and Modern age 